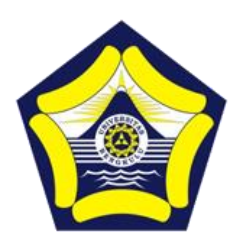

\title{
Teaching English Writing through Cubing Method to the Tenth Grade of High School Students
}

\author{
Hendriadi Ahmad* \\ The Muhammadiyah University Palembang, Indonesia \\ *Email: hendriadiaz06@gmail.com
}

DOI: https://doi.org/10.33369/jeml.2.1.29-33

\begin{abstract}
The main objective of this study was to find out whether it is effective or not to teach English writing through cubing method to the tenth grade students of SMA Rahmaniyah Sekayu. This study used one group pre-test post-test design, where one group that becomes experimental group and used pre-test post-test result to compare the effectiveness in using cubing method. There were four classes or 82 students as the population, and one class or 22 students were taken as the sample. The data collected through test and analyzed by match t-test analysis. The result of test calculation shown that t-obtained was 10.198 it was higher than the critical value in the t-table was 2.0789 so that $10.198>2.0798$. It means that the research hypothesis (Ha) was accepted. It can be concluded that cubing method was significantly effective to teach English writing.
\end{abstract}

Keywords: English writing, cubing method, student, high school.

\section{INTRODUCTION}

Nowadays, in Indonesia the teachers of English have used some methods or techniques that is a crucial to improve the learning processes. Every method or technique helps teachers and students in teaching learning activities. To understand and interpret some topics, each method or technique that used should cover four skills of languages. They are reading, writing, listening and speaking skill. From this statement writing is one of skill that should be mastered by the teachers and students in learning English (Mistar, 2005).

Based on Dixon and Nessel states that expressing meaning through writing requires more effort that recognizing listening or reading is more difficult than expressing meaning through speaking because the writer must follow the convention of spelling and punctuation that make the message understandable by others (Yurningsih, 2011).

In learning and teaching English, writing is one of skill that involves many aspects, like grammar, vocabulary, culture, and so on. So, in learning writing we need much time to practice in order to develop our ability in writing. Because of that problem, a teacher of English has to be creative to find a strategy or method to make writing easier and more interesting. Here, a technique that can be used is cubing method. Cubing is a good way to look at a person, object, feeling, or idea from six different perspectives (Gillard, 2008). Cubing is a brainstorming technique that can build critical thinking exercise to help students express their opinion (Nichol, 2011; Abedianpour, 2018). Based on explanation above, the author looks further the effectiveness of using cubing method in writing English to the tenth grade students of SMA Rahmaniyah Sekayu.

\section{RESEARCH METHODS}

This research used experimental, quantitative approach. The type of method is one group pre-test posttest design, where one group that became experimental group and used pre-test post-test result to compare the effectiveness in using cubing method in teaching The location of the resarch was done for English writing at SMA Rahmaniyah Sekayu, Palembang - Indonesia. One class, class X4, was taken as the experimental group. The information of sample are: male 13 students, female 9 students, total 22 students. The results were then analyzed using statistics program and interpretated. 


\section{RESULTS AND DISCUSSION}

The results of the study be seen in the table 1 . From the data, it can be seen that the lowest score was 14 which was got by three students (13.6\%), and there was one student who got the highest score or 24.5 (4.5\%), four students got 20 (18.2\%), three students got $19.5(13.6 \%)$, and then score 15 and $22.5(9.1 \%)$ were got by two students, one students got 14.5 (4.5\%), one students got $16(4.5 \%)$, one students got 17 (4.5\%), one student got 20.5 (4.5\%), one student got 21.5 (4.5\%), one student got 22 (4.5\%), and one student got $24(4.5 \%)$.

Table 1. The students Pre-test Score

\begin{tabular}{|r|l|r|r|r|r|}
\hline \multicolumn{1}{|c|}{} & Frequency & Percent & Valid Percent & Cumulative Percent \\
\hline Valid & 14 & 3 & 13.6 & 13.6 & 13.6 \\
& 14.5 & 1 & 4.5 & 4.5 & 18.2 \\
& 15 & 2 & 9.1 & 9.1 & 27.3 \\
& 16 & 1 & 4.5 & 4.5 & 31.8 \\
& 1 & 4.5 & 4.5 & 36.4 \\
& 19.5 & 3 & 13.6 & 13.6 & 50.0 \\
& 4 & 18.2 & 18.2 & 68.2 \\
& 20.5 & 1 & 4.5 & 4.5 & 72.7 \\
21.5 & 1 & 4.5 & 4.5 & 77.3 \\
22 & 1 & 4.5 & 4.5 & 81.8 \\
22.5 & 2 & 9.1 & 9.1 & 90.9 \\
& 24 & 1 & 4.5 & 4.5 & 95.5 \\
& 24.5 & & 4.5 & 4.5 & 100.0 \\
& & & & \\
& Total & 22 & 100.0 & 100.0 & \\
\hline
\end{tabular}

Table 2 shows descriptive of statics from pre-test score of sample students. From table 2 the author found that the mean or average score was 18.8864 , the median was 19.75 and mode of the test was 20 . The minimum of the pre-test score was 14 , while the maximum was 24.5 and the standard error of mean 0.72370 .

Table 2. Statistics of Pretest

\begin{tabular}{|l|r|}
\hline N $\quad$ Valid & 22 \\
Mean & 22 \\
Std. Error of Mean & 18.8864 \\
Median & .72370 \\
Mode & 19.7500 \\
Std. Deviation & 20.00 \\
Minimum & 3.39443 \\
Maximum & 14.00 \\
Sum & 24.50 \\
\hline
\end{tabular}


Table 3 below, shows the result of post-test;

Table 3. The Result of Post-test Score of Sample Students

\begin{tabular}{|ll|r|r|r|r|}
\hline & & Frequency & Percent & Valid Percent & Cumulative Percent \\
\hline Valid & 20 & 1 & 2.3 & 4.5 & 4.5 \\
& 22.5 & 2 & 4.5 & 9.1 & 13.6 \\
& 23 & 1 & 2.3 & 4.5 & 18.2 \\
& 23.5 & 2 & 4.5 & 9.1 & 27.3 \\
& 24 & 3 & 6.8 & 13.6 & 40.9 \\
& 24.5 & 1 & 2.3 & 4.5 & 45.5 \\
& 25 & 5 & 11.4 & 22.7 & 68.2 \\
& 25.5 & 1 & 2.3 & 4.5 & 72.7 \\
& 26 & 3 & 6.8 & 13.6 & 86.4 \\
& 27 & 2 & 4.5 & 9.1 & 95.5 \\
& 28 & 1 & 2.3 & 4.5 & 100.0 \\
& Total & 22 & 50.0 & 100.0 & \\
Missing & System & 22 & 50.0 & & \\
Total & & 44 & 100.0 & & \\
\hline
\end{tabular}

From the data above, it could be seen that five students (11.4\%) got 25, three students $(6.8 \%)$ who got 24 , two students $(6.8 \%)$ got 26 , two students $(4.5 \%)$ got 22.5 , two students got 23.5 (4.5\%), two students got $27(4.5 \%)$, one student got $20(2.3 \%)$, one student got 23 (2.3\%), one student got $24.5(2.3 \%)$, one student got $25.5(2.3 \%)$, and the highest score 28 was got by one student $(2.3 \%)$. We can see from table 4 , descriptive of statics from post-test score of sample students.

Table 4. Statistics of Posttest

\begin{tabular}{|l|r|}
\hline N $\quad$ Malid & 22 \\
Mean & 22 \\
Std. Error of Mean & 24.6364 \\
Median & .37965 \\
Mode & 25.0000 \\
Std. Deviation & 25.00 \\
Minimum & 1.78073 \\
Maximum & 20.00 \\
Sum & 28.00 \\
\hline
\end{tabular}

From the table above, the author found the mean or average score was 24.6364 , the median was 25 , and mode of the test was 25 , the standard error of mean was 0.37965 , the standard deviation was 1.78073 , the minimum score was 542 .

Table 5 shows the paired sample statistics, the author found it by pairing the post-test score with the pretest score. Mean, standard deviation, and standard error of mean score can be seen below:

Paired Samples Statistics

\begin{tabular}{|ll|r|r|r|l|}
\hline & & Mean & $\mathrm{N}$ & Std. Deviation & Std. Error of Mean \\
\hline Pair 1 & pretest & 18.8864 & 22 & 3.39443 & .72370 \\
& posttest & 24.6364 & 22 & 1.78073 & .37965 \\
\hline
\end{tabular}

From the table above we can see pre-test score, the mean was 18.8864 , standard deviation was 3.39443 and standard error of mean was 0.72370 , while for the post-test score the mean was 24.6364 , standard deviation was 1.78073 and standard error of mean was 0.37965 . 
Figure 1 below shows the result paired of pre-test post-test of the sample students. In general, the posttest results are higher than those of pre-test.

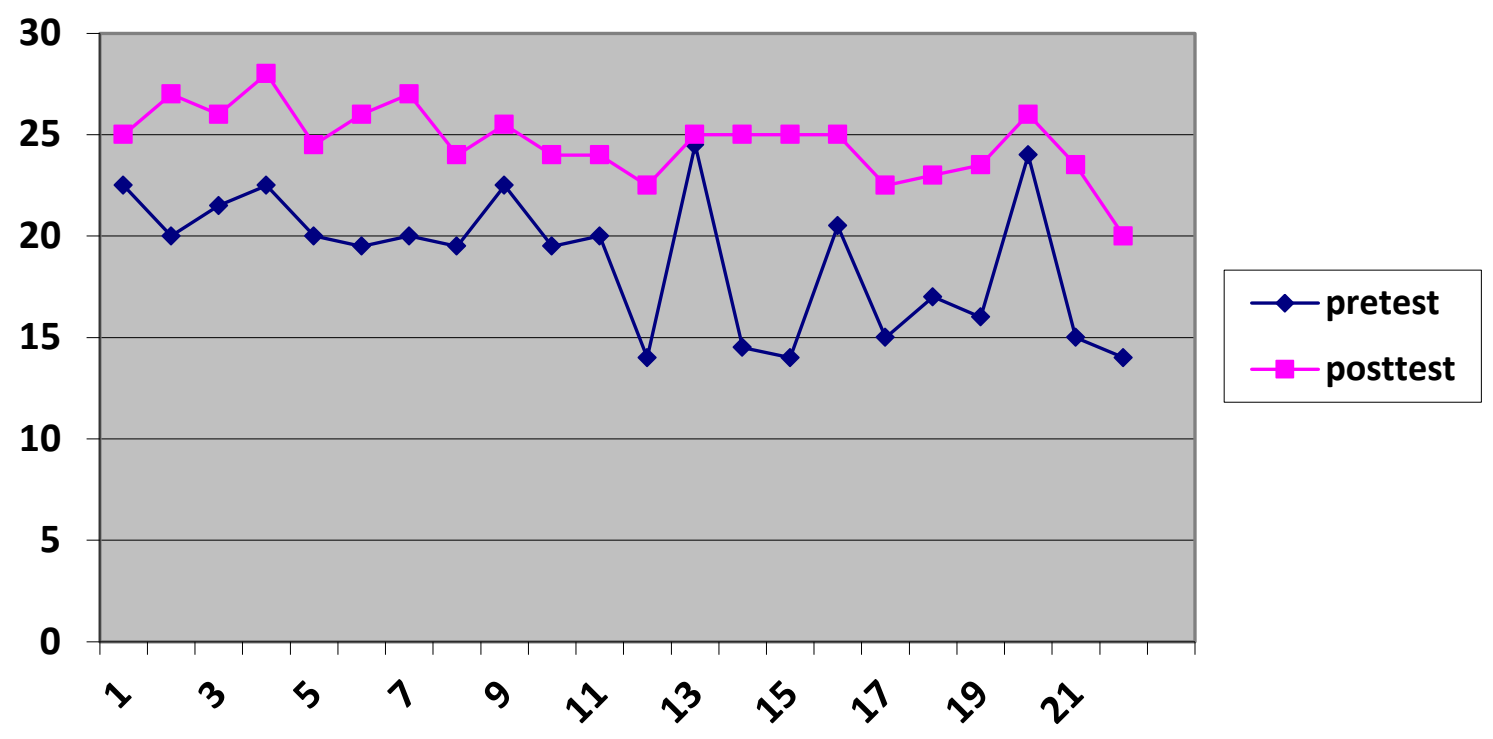

Figure 1. Paired of pre-test and post-test

Table 6 shows the result of paired sample t-Test calculation of sample students using SPSS 16.0.

Table 6. The Result Of Paired Sample t-Test Calculation Of Sample Students

\begin{tabular}{|c|c|c|c|c|c|c|c|c|}
\hline & \multicolumn{5}{|c|}{ Paired Differences } & \multirow[b]{3}{*}{$t$} & \multirow[b]{3}{*}{ df } & \multirow[b]{3}{*}{$\begin{array}{l}\text { Sig. }(2- \\
\text { tailed) }\end{array}$} \\
\hline & \multirow[b]{2}{*}{ Mean } & \multirow{2}{*}{$\begin{array}{c}\text { Std. } \\
\text { Deviatio } \\
\mathrm{n}\end{array}$} & \multirow{2}{*}{$\begin{array}{l}\text { Std. } \\
\text { Error } \\
\text { Mean }\end{array}$} & \multicolumn{2}{|c|}{$\begin{array}{l}95 \% \text { confidence } \\
\text { interval of the } \\
\text { Difference }\end{array}$} & & & \\
\hline & & & & Lower & Upper & & & \\
\hline $\begin{array}{ll}\text { Pair 1 } & \text { pretest } \\
& \text { Posttest }\end{array}$ & -5.75000 & 2.64463 & .56384 & -6.92256 & -457744 & -10.198 & 21 & .000 \\
\hline
\end{tabular}

Table 6 displayed the score of the degree of freedom (df) was 21, and the t-obtained 10.198. Based on the critical value of the t- table at 0.05 of level significance for 21 were 2.0798 . So that the alternative hypothesis (Ha) was accepted and null hypothesis (Ho) was rejected because the t-obtained exceed and higher than t-table and $\mathrm{p}(.000)$ was less or lower than $\alpha(0.05)$. it means there was significant difference between the students' score in the pre-test and those increase highly in post-test. From the data above, it can be concluded that the score of sample students increased highly after treated by using cubing method. In other word, it was effective to teach writing English through cubing method at SMA Rahmaniyah Sekayu.

\section{CONCLUSIONS}

Based on the description above the author concluded that from the result of paired score from pre-test and post-test of sample students, the highest score was 24.5 , while the lowest score was 14 and the average score was 18.8864 . while the post-test the highest score was 28 , the lowest score was 20 , and the average score was 24.6364 . The analysis through t-test formula was probability $(p)$ value was .000 , it was identified lower or less than alpha $(\alpha=0.05)$. It mean that, teaching English writing through cubing method was effective to the tenth grade students of SMA Rahmaniyah Sekayu.

\section{REFERENCES}

Abedianpour, S., \& Omidvari, A. (2018). Brainstorming strategy and writing performance: Effects and attitudes. Journal of Language Teaching and Research, 9(5), 1084-1094. 
Arikunto, Suharismi. 2010. Prosedur Penelitian Suatu Pendekatan Praktik. Jakarta: Rineka Cipta.

Gillard, Mariah Bennett. 2008. Cubing: 3-D Approach to Brainstorming. Retrieved from http://psuwritingcenter.blogspot.com/2008/cubing-3-d-approach-to-brainstorming.html.

Mistar, J. (2005). Teaching English as a foreign language (TEFL) in Indonesia. Teaching English to the world: History, curriculum, and practice, 71-80.

Nichol, Mark. 2011. brainstorming strategies for writers. Retrieved from https://www.dailywritingtips.com/5-brainstorming-strategies-for-writers/

Yurningsih. 2011. Developing writing skill of the tenth grade students of SMA Muhammadiyah 6 by Using Writing Diary. Unpublished Graduate Thesis. Faculty of Teacher Training and Education, University of Muhammadiyah, Palembang. 